\section{IJßER}

ISSN: 2149-5939
International Journal of Social Sciences and Education Research

Online, http://dergipark.gov.tr/ijsser

Volume: 3(1), 2017

\title{
Türk Silahlı Kuvvetlerinin uygulamaları bağlamında anadili Türkçe olmayanlara Türkçe öğretimi
}

\author{
Teaching Turkish to non-native speakers within the context of Turkish Armed \\ Forces practices
}

\begin{abstract}
Ali Taştekin ${ }^{1}$
Received Date: 03 / 09 / 2016

Accepted Date: 12 / 11 / 2016

$\ddot{O} z$

Türk Silahlı Kuvvetlerinin yabancılara Türkçe ögretme faaliyetinin tarihi süreci henüz tam olarak tespit edilmemiştir. Ancak Türkiye Cumhuriyetinin kurulușundan sonra bilinen ilk Misafir Askerî Personel (MAP)'e Türkçe eğitimi, "24 Nisan 1933 tarih ve 14234 sayll, Gazi Mustafa Kemal imzalı kararnamede, Suudi Arabistan Hükümeti'nin "Türkiye Harp ve Tayyare Mektepleri"ne ögrenci göndermek istemesi üzerine alınan kabul kararl" ile başladı̆̆ kabul edilmektedir. TSK'deki ATOTÖ etkinliğinde, "Seçmeci (Eklektik) Yöntem”'in uygulandiğl, Türkçenin öğretiminde, dört dil becerisine (okuma, yazma, anlama, konuşma) imkânlar ölçüsünde yeterli zaman ayrıldı̆̆ ve dört temel beceriye de aynı derecede önem verildiği gözlenmiștir. TSK'nin örnek uygulamalarından bilim dünyasının haberdar olmasını sağlamak maksadıyla, ulusal ve uluslararası çalıştaylara "Türkçenin mesleğe yönelik ögretimi”, "Ana dili Türkçe olmayan yetişkinlere belirli bir amaca yönelik Türkçe ögretimi” vb. konuların da dahil edilmesinin yararlı olacă̆ de ğerlendirilmektedir. MAP'a Türkçenin yabancı dil olarak öğretilmesinde göreceli olarak kimi sorunlar mevcuttur. Bu sorunların alınan ilave tedbirlerle çözülmeye çalışıldığı, ilk defa 2005 yılında uygulanan TAS sinavlarına göre yurt dışından kursiyer seçiminin, Türkçe Tekâmül Kursunun kalitesine olumlu katkı sağladığı tespit edilmiştir. Yabancılara Türkçe öğretimi konusunda yaşanan sıkıntıların tespiti için deneysel araştırmaların sayısının artırılmasına yönelik önlemler alınmalıdır. Öğretim programları uzman kişilerce hazırlanmalı ve güncellenecek program için kurulacak çalışma gruplarına TSK'den de personel dâhil edilmelidir.
\end{abstract}

Anahtar Sözcükler: Türkçe ögrretimi, Yabancı dil, Türk Silahlı Kuvvetleri, Askeri personel.

\begin{abstract}
The historical process of Turkish Armed Forces' activities concerning teaching Turkish to foreigners has not yet been completely identified. However, the first known Turkish language education given to Guest Military Personnel after the foundation of Turkish Republic was recorded in the enactment signed by Ghazi Mustafa Kemal on 24 April 1933 and issued 14234 on "the admittance decree regarding the Saudi Arabia Government's wish to send students to "Türkiye Harp ve Tayyare Mektepleri" (Turkish Schools of War and Aviation) and this is acknowledged as the beginning of this practice. It was observed that in this Teaching Turkish to Non-Native Speakers activity performed by Turkish Armed Forces, "Eclectic Method" was applied and four language skills (reading, writing, comprehension, speaking) were allocated an adequate amount of time and the same amount of importance within the bounds of possibility while teaching Turkish. In order to make this exemplary practice of Turkish Armed Forces known in the science world, it would be beneficial to include topics such as "Teaching Turkish for Professional Purposes" and "Teaching Turkish to non-native adults for specific purposes," etc. in national and international workshops. There are certain relative problems in teaching Guest Military Personnel Turkish as a foreign language. It was determined that these problems were tried to be solved by means of additional precautions and that selecting the trainees from abroad according to TAS exams first applied in 2005 has had a positive contribution to the quality of Türkçe Tekâmül Kursu (Turkish Improvement Course). Precautions must be taken in order to increase the number of experimental research made to identify the problems encountered in teaching Turkish to foreigners. Training programs must be prepared by experts and Turkish Armed Forces staff should also be included in research groups to be founded for the update of the program.
\end{abstract}

Keywords: Turkish language education, foreign language, Turkish Armed Forces, military personnel.

\footnotetext{
${ }^{1}$ Yrd. Doç. Dr., İstanbul Arel Üniversitesi Fen Edebiyat Fakültesi, İstanbul, TÜRKIYYE, alitastekin@ arel.edu.tr
} 
Taştekin, A. (2017). Türk Silahlı Kuvvetlerinin uygulamaları bağlamında anadili Türkçe olmayanlara Türkçe öğretimi. International Journal of Social Sciences and Education Research, 3(1), 171-183.

\section{Giriș}

Anadili Türkçe olmayanlara Türkçe öğretimi etkinliği, Türkiye ve pek çok yabancı ülkedeki resmî ve özel kurumlarda; muhtelif amaç, kapsam ve yöntemlerle yürütülmektedir. Bilgisayar teknolojisinin gelişmesine paralel olarak Genel A $\breve{g}$ 'da da Türkçe öğreten sitelerin sayısı giderek artmaktadır. Bazı kurum ve sitelerde "Türkçenin yabancı dil olarak öğretilmesi, Yabancılara Türkçe öğretimi veya Yabancı dil olarak Türkçenin öğretimi” vb. biçimlerde ismi konan etkinliği Anadili Türkçe Olmayanlara Türkçe Öğretimi (ATOTÖ) olarak adlandırmanın daha yararlı olacağını değerlendirdiğimizden bu adı kullanmayı tercih edeceğiz.

ATOTÖ faaliyetinin tarihi, yazılı Türk edebiyatının bilinen en eski metinlerinin oluşturulduğu sekizinci yüzyıla kadar uzanır. Göktürk kitabelerinde yer alan Türkçe ve Çince metinler bu alandaki tespit edilen ilk örneklerdir. ATOTÖ'nin, Batı'da 15. asırdan sonra misyoner yetiştirme faaliyetleri kapsamında başladığı kabul edilmektedir. Avrupalıların Türkçe öğrenmeleri, Osmanlı Devleti'yle ticarî ve siyasî ilişki kurmalarıyla devam etmiş ve Avrupa' da birçok üniversitede Türkoloji bölümleri açılmıştır.

Tarihî süreçte ATOTÖ çalışmaları sürekli artan bir ivme kazandığından, son zamanlarda bu konudaki bilimsel çalışmalar hem nicelik hem de nitelik bakımından dikkat çekici boyutlara ulaşmakta, ulusal ve uluslararası Türk dili konulu kurultay ve çalıştaylarda ATOTÖ konusuna da yer verilmektedir. Bu sayede bilimsel makale ve bildiriler ile müstakil kitaplar yazılmakta; yapılan çalışmalar derlenerek tasnife tabi tutulmaktadır.

2012 yılına kadar üretilen ATOTÖ konulu kitap, makale, yüksek lisans ve doktora tezleri ile bildirilerin derlendiği bir makalede, elde edilen kaynakların yazar soyadına göre sıralı künyeleri verilmiştir (Göçer, Tabak ve Coşkun 2012).

Bir başka çalışmada "yabancılara Türkçe öğretimiyle ilgili 186 kitap, 155 makale, 139 yüksek lisans tezi ve 35 doktora tezi olmak üzere toplam 174 tez, 229 adet seminer, kurultay ve sempozyum bildirisi tespit edilmiştir. Kitaplar; yerli kitaplar ile setler olmak üzere iki ayrı başlık altında toplanmıştır. Makaleler alfabetik sıraya dizilmiş; tezler, yüksek lisans ve doktora tezleri olarak iki alt başlıkta belirtilmiştir. Sempozyum, seminer ve kurultay bildirileri de önceki sempozyum, seminer ve kurultaylara göre verilmiştir." (Kahriman, Dağtaş ve diğerleri, 2013: 80-132).

Bu tür kaynak derleme çalışmaları, henüz gelişmekte olan ATOTÖ etkinliğine ait kısıtlı kaynaklara kolay ulaşma imkânı vermenin yanı sıra; araştırmacıların bu alandaki problem sahaları, ele alınan ve araştırılması gereken konular, yöntemler ile diğer gelişmeler hakkında inceleme, araştırma ve değerlendirme yapmalarını kolaylaştırmaktadır.

Cumhuriyetin ilk onuncu yılından sonra yabancı subaylara Türkçe öğretilmeye başlanan Türk Silahlı Kuvvetleri (TSK)'nde ATOTÖ etkinliği ile ilgili kurumsallık büyük ölçüde tamamlanmıştır. Sivil kurumlarda ise “Türkçenin yabancı dil olarak öğretimi 1990'lı yıllardan sonra akademik çalışmalara konu olmaya başlamıştır. Türkiye'de tezli ve tezsiz yüksek lisans düzeyinde "Yabancı Dil Olarak Türkçe Öğretimi" programları; Dokuz Eylül Üniversitesi, Gazi Üniversitesi, Hacettepe Üniversitesi, İstanbul Üniversitesi ve Yıldız Teknik Üniversitesi’nde mevcuttur. Ancak lisans düzeyinde "Yabancı Dil Olarak Türkçe Öğretimi” programı hiçbir üniversitede henüz açılmamıştır. Bu sebeple Türkçe eğitimi bölümlerinde kurulması gerekli görülen ana bilim dallarından birisi de "Yabancılara Türkçe Öğretmenliği Ana Bilim 
Taştekin, A. (2017). Teaching Turkish to non-native speakers within the context of Turkish Armed Forces practices. International Journal of Social Sciences and Education Research, 3(1), 171-183.

Dalı” olarak önerilmektedir. Bu sayede yabancılara Türkçeyi öğretecek nitelikli öğretmenlerin yetiştirilmesi sağlanacaktır." (Göçer, Tabak ve Coşkun 2012).

Türkiye'de Türkçenin eğitim öğretimi için hazırlanan ve kullanılan kitaplar içerik ve nitelik bakımından her geçen gün daha kaliteli olma yolundadır. 2008 yılında Doğu Akdeniz Üniversitesi Eğitim Fakültesi Türkçe Eğitimi Bölümünün düzenlediği "Uluslararası Türkçe Eğitimi ve Öğretimi Sempozyumu"nda sunulan bir bildiride bu konudaki mevcut kitaplar tespit edilmiş ve "Ders kitabı dışında malzemeler kullanma" oranının \% 37 olduğu göz önünde tutulursa adı geçen ders kitaplarının birincil dil öğretim malzemesi olduğu görülmektedir.” (Açık 2008) bilgisi paylaşılmıştır. Ders kitabı ve yardımcı kaynaklar konusunda daha çok mesafe alınması gerekmektedir.

Türkiye Türkçesi günümüzde; Amerika, Asya, Avrupa ve Afrika ülkelerindeki üniversitelerde öğretilen yabancı dillerin başında yer almaktadır. Yabancıların Türkçe öğrenme talebindeki artışa paralel olarak Türkçe öğretim yöntem, araç ve gereçleri ile öğretim ortamlarının kalitesinin de artması muhtemeldir.

Dünyanın 12 milyon $\mathrm{Km}^{2}$ lik çok geniş bir coğrafyasında, yaklaşık 250 milyon insan tarafindan Türkçe (lehçe ve ağızlarıyla birlikte) konuşulduğu bilinmektedir. Ayrıca yedi ülkede ${ }^{1}$ resmî dil olarak kullanılan Türkçenin kelime sayısı bir milyonun üzerindedir. Bazı özerk Türk cumhuriyetlerinde ve Türk bölgelerinde de Türkçe resmi dil olarak kabul edilmektedir. ${ }^{2}$

Bugünkü Türk yazı dilleri Altay, Azerbaycan, Balkar, Başkurt, Çuvaş, Gagavuz, Hakas, Karaçay, Karakalpak, Kazak, Kırgız, Kumuk, Nogay, Özbek, Tatar, Tuva, Türkiye, Türkmen, Uygur ve Yakut Türkçeleridir. Türk lehçe ve şivelerinin bazıları boyun kendi adını bazıları da boyun yaşadığı coğrafyanın adını taşımaktadır. Türkiye Türkçesi dışındaki lehçe ve ağızların yabancılara öğretimi konusu ile bu dillerin Türkiye'de yabancı dil olarak algılanması sorunu göz ardı edilmektedir. Türkçenin tarihî, coğrafî̀ ve kültürel etki alanları dikkate alındığında yabancıların Türkçeye, özellikle Türkiye Türkçesine ilgilerinin her geçen gün artacağı ve bu bağlamda ATOTÖ etkinliğinin daha fazla önem arz edeceği değerlendirilmektedir.

\section{15 Temmuz 2016 darbe girişiminden önce ATOTÖ etkinliğinin TSK'deki durumu}

Sivil, resmî ve özel kurumların yanı sıra, TSK'nin muhtelif kurumlarında da askerî eğitim almak üzere Türkiye'ye gönderilen Misafir Askerî Personel (MAP)'e Türkçe öğretilmekteydi. ${ }^{3}$ Ayrıca yurt dışında TSK'nin desteğiyle açılan bazı dost ve müttefik ülkelerdeki Türkçe lisan dershanelerinde ${ }^{4}$ de ilgili ülkenin askerî personeline Türkçe eğitimi verilmekteydi.

TSK'ndeki ATOTÖ faaliyetinin tarihi süreci henüz tam olarak tespit edilememiştir. Türkiye Cumhuriyeti'nin kuruluşundan sonra bilinen ilk MAP'e Türkçe eğitimi “24 Nisan 1933 tarih ve 14234 sayılı, Gazi Mustafa Kemal imzalı kararnamede, Suudi Arabistan Hükümeti'nin “Türkiye Harp ve Tayyare Mektepleri”ne öğrenci göndermek istemesi üzerine alınan kabul kararı" ile başlamıştır ve "Türk Hava Kuvvetleri, 1955 yılında Libyalı bir öğrenciyi kabul ederek tarihinde ilk kez misafir askeri öğrenci almıştır.” (Bağdaş 2015). TSK'nin Cumhuriyet

\footnotetext{
${ }^{1}$ Türkiye, Azerbaycan, Kazakistan, Kırgızistan, Özbekistan, Türkmenistan, Kuzey Kıbrıs Türk Cumhuriyeti.

${ }^{2}$ Çuvaşça, Kumukça, Karaçay-Balkarca, Tatarca, Başkurtça, Yakutça, Hakasça, Tuvaca, Altayca ve Uygurca.

3 TSK'nde "Yabancılara Türkçe öğretme" faaliyeti, "misafir askerî personele Türkçe öğretme" şeklinde adlandırılır. Kursiyerlere "yabancı" denmez, onlar "misafir" kabul edilir. Bu durum kursiyerler üzerinde önemli bir motivasyon sağlamaktadır.

${ }^{4}$ Eylül 2012 itibariyle yurt dışında 18 ülkede 23 Türkçe lisan dershanesi mevcuttur.
} 
Taştekin, A. (2017). Türk Silahlı Kuvvetlerinin uygulamaları bağlamında anadili Türkçe olmayanlara Türkçe öğretimi. International Journal of Social Sciences and Education Research, 3(1), 171-183.

öncesi dönemlerde yabancı askerî personele Türkçe öğretme faaliyeti, araştırılması gereken önemli bir konu olarak dikkati çekmektedir.

Millî Savunma Bakanlığının 2011 Yılı Faaliyet Raporuna göre dost ve müttefik ülkelerle imzalanan anlaşmalar kapsamında bahse konu ülkelere mensup Misafir Askerî Personel (MAP)'e TSK bağlısı eğitim kurumlarında ve mobil eğitim timleri vasıtasılla kendi ülkelerinde; eğitim, öğretim ve çeşitli kurslar verilmektedir. "2011 yılı içerisinde Kosova ile ASEİ̧̧1 Anlaşması imzalanmış olup, anlaşma imzalanan ülke sayısı 49'a yükselmiştir. 2011-2012 Eğitim Döneminde 25 ülkeden 1.413 MAP'a eğitim/kurs verilmiştir. Toplamda 51 dost ve müttefik ülkeye mensup 25.200 MAP'a eğitim/kurs verilmiştir. 2011 yılı içerisinde Senegal ve Kosova'da Türkçe Dil Dershanesi kurulmuştur. Böylelikle dost ve müttefik 16 ülkede (Afganistan, Arnavutluk, Bangladeş, Bosna-Hersek, Gürcistan, Kazakistan, Kırgızistan, Kosova, Makedonya, Moğolistan, Romanya, Senegal, Tunus, Türkmenistan, Ukrayna ve Ürdün) kurulan Türkçe Dil Dershanesi sayısı 21'e çıkmıştır. 391'i 2011-2012 Eğitim Yılında olmak üzere, toplam 3.782 personel kurs görmüştür." (MSB 2015).

TSK'nde MAP'e verilen Türkçe öğretimi; her kuvvetten rütbeli personele Kara Kuvvetleri Lisan Okulu (K.K.Lisan Okulu)'nda, öğrencilere ise eğitim gördükleri kurumlarda verilmekteydi. Türkçe öğrenen MAP'den askerî liseler, harp okulları, Gülhane Askeri Tıp Akademisi, sınıf okulları ve harp akademilerinde öğrenim görenlere öğrenci; lisan okulları vb. kurumlarda Türkçe öğrenen rütbeli personele ise kursiyer denmekteydi.

Son zamanlara kadar ASEİŞ anlaşmaları kapsamında dost ve müttefik ülkelerden harp okullarında, astsubay meslek yüksekokullarında ve bazı askeri liselerde öğrenim görmek üzere Türkiye'ye gelen MAP'e bu okulların Türkçe hazırlık sınıflarında bir sene Türkçe hazırlık eğitimi verilmekteydi. TSK'nin yurt içi ve yurt dışı kurumlarında MAP'e Türkçe öğretimi faaliyetleri; MY 164-5 (B) Misafir Askeri Personelin Eğitim ve Öğretim Esasları Yönergesi ile KKY 164-2 Kara Kuvvetleri Lisan Eğitim Yönergesi esaslarına göre yürütülmekteydi.

31 Mart 2014 tarihinde yayımlanan uygulama emriyle, tüm askerî eğitim kurumlarındaki yabancı dil eğitimlerinde dilbilgisel öğretimden ziyade, başlangıçta ağırlıklı olarak okuma ve dinleme becerilerinin geliştirilmesi esasına dayalı Anlama Odaklı Öğrenme modeline geçilmişti. Bu durum Türkçe öğretimine de yansıtılmaktaydı.

K.K.Lisan Okulundaki Türkçe öğretimi; harp akademileri ve sınıf okullarında öğrenim görecek MAP ile kendi ülkesinde Türkçe lisan dershanelerinde öğretmenlik yapacak MAP'e verilen eğitimi kapsamaktaydı. Bu okulda; 36 hafta süreyle Türkçe temel - tekâmül, 13 hafta süreyle de Türkçe tekâmül kursu verilmekte, haftada beş gün altışar saat ders işlenmekte ve dersler en fazla 15'er kişilik sınıflarda yapılmaktaydı.

2009-2010 eğitim-öğretim yılından itibaren okutulan Ankara Üniversitesinin hazırladığ "Yeni HİTiT" ders kitaplarının yerine, 2015-2016 eğitim-öğretim y1lından itibaren İstanbul Üniversitesi Dil Merkezinin hazırladığ Öğrenme modeline uygun, okuma ve dinleme ağırlıklı, kursiyer ders ve çalışma kitaplarından oluşan "İSTANBUL Yabancılar İçin Türkçe Ders Kitabı" okutulmaya başlanmıştır. Ayrıca

\footnotetext{
${ }^{1}$ ASEİŞ: Askerî Eğitim İşbirliği
} 
Taştekin, A. (2017). Teaching Turkish to non-native speakers within the context of Turkish Armed Forces practices. International Journal of Social Sciences and Education Research, 3(1), 171-183.

MAP'ın dinleme becerisini geliştirmek maksadıyla "Misafir Askerî Personel İçin Türkçe Dinleme Metinleri" hazırlanarak kullanıma sunulmuştur. Tüm ders materyali Türkçe dershanelerindeki akı1lı tahtalara yüklenmiş olup, derslerde Genel A ğ (İnternet)'dan yararlanılmaktaydı.

TSK bünyesinde MAP'a Türkçe eğitimi veren tüm eğitim kurumları arasında koordinasyonu sağlamak ve bu alanda kullanılmak üzere materyal paylaşımını sağlamak üzere Genelkurmay Başkanlığı tarafından Türkçenin Yabancı Dil Olarak Öğretimi Çalışma Grubu teşkil edilmiştir. Aynı kapsamda K.K.Lisan Okulu sorumluluğunda 7 dilde oluşturulan K.K.Lisan Eğitim Portalına MAP'a Türkçe sayfası da eklenerek Türkçe öğretimine yönelik materyal paylaşımı pratik hale getirilmiştir.

K.K.Lisan Okulunda dershane ortamında verilen müfredata dayalı Türkçe eğitiminin yanı sıra hafta içi Ders Nitelikli Kültür Gezileri ve hafta sonu Sosyal Etkinlikleri düzenlenerek ülkemizin güzelliklerini, zengin Türk kültürü ve insanımızın misafirperverliğini tanıtma, onlara tarihî ve turistik mekânlarda pratik yapma imkânı yaratılmaktaydı. Ayrıca MAP'ın kullanımına yönelik olarak her ay "Türkçenin Sesi" adlı bilgi dokümanı hazırlanmakta, Türkçe öğrenen kursiyerlerin okumaları sağlanmaktaydı. Böylece MAP, sadece Türkçe öğrenmekle kalmamakta; Türk kültürünü, Türk gelenek ve göreneklerini de öğrenen bir Türk dostu olarak K. K. Lisan Okulundan mezun olmaktayd.

Dersler; içeriğine uygun olarak bilgisayar destekli eğitim dershanesi, çok maksatlı dershane, konuşma kulüpleri ve kültürel gezilerle doğal ortamlarda işlenmekteydi. Üretilen eğitim yardımcı malzemeleri (EYM) ${ }^{1}$ derste ve ders dışı zamanlarda MAP'in kullanımına sunulmaktaydı. EYM olarak kullanılan Müzikle Türkçe Öğretim Seti, MAP'e ders dışı zamanlarda Türk dilini ve kültürünü müzik yoluyla öğretmekteydi. Ayrıca MAP'in günlük konuşma becerisini geliştirmek maksadıyla 10 Dilde Türkçe Günlük Konuşma Kılavuzu² kullanılmaktaydı.

Türkçe Tekâmül Kursu görmek isteyen MAP arasından nitelikleri uygun olanları seçmek, adayların Türkçe anlama seviyesini belirlemek, Türkçeye olan ilgiyi artırmak maksadıyla Türkçe Anlama Seviye Tespit Sınavı (TAS) seti kullanılmaktaydı. Bilgisayar ortamında icra edilecek şekilde hazırlanan TAS, 32 ülkedeki askeri ataşeliklerimizde uygulanmakta; bu s1navlarda başarılı olan yabancı askerî personel Türkiye'deki kurslara tefrik edilmekteydi. 100 üzerinden 60 ve üstü not alanlar Türkiye'deki Türkçe tekâmül(orta düzey) kursuna, daha düşük alanlar ise temel (başlangıç) kursa seçilmekteydi. ${ }^{3}$ Kısımlarda (derslik) kursiyerler U düzeninde oturmaktaydı. Bu oturma düzeni kursiyerler arasındaki iletişimi güçlendirmekte, ders ortamının daha verimli olmasına imkân sunmaktaydı.

Ölçme ve değerlendirmede dört beceriyi ölçmeye yönelik sınav yöntem ve içerikleri oluşturulmakta ve uygulanmaktaydı. Ayrıca Türkiye'deki harp okulları ile harp akademilerinde eğitim görecek MAP'in seçiminde kullanılmak maksadıyla hazırlanan ve İngilizce TOEFL sınav sisteminin bir benzeri olan "Evrensel Dil Türkçe Seviye Tespit Sınavı" (EDTS) seti bulunmaktaydi.

\footnotetext{
${ }^{1}$ Türkçe Anlama Sınavı (TAS), Türkçe Günlük Konuşma Seti, On Dilde Konuşma Kılavuzu, Askerî Terminoloji Kitabı, Müzikle Türkçe Öğretimi Seti, Hikâyelerle Türkçe Öğretimi Kitabı, MAP için Dil bilgisi CD'si, Türkiye ve İstanbul Tanıtım CD'si, Türkçe ile Ortak Kelimeler Sözlükleri (8 ayrı dilde) vb.

${ }^{2}$ Türkçe, İngilizce, Arapça, Rusça, Farsça, Gürcüce, Yunanca, Boşnakça, Fransızca, Bulgarca dillerinde kelime ve cümle kalıpları konulara göre gruplandırılarak verilmiştir.

${ }^{3}$ Bu sinav, American Language Course (ACL) sinavı benzeri bir sinavdır.
} 
Taştekin, A. (2017). Türk Silahlı Kuvvetlerinin uygulamaları bağlamında anadili Türkçe olmayanlara Türkçe ögretimi. International Journal of Social Sciences and Education Research, 3(1), 171-183.

Ders dışı eğitim ortamları da MAP'in Türkçe öğrenme ve pratik yapma imkânlarıyla donatılmakta, misafirhanede Türkçe tv. izlemek ve bilgisayar, kaset / cd çalar vb. araçları kullanmak için gerekli araç, gereç ve aygitlar sunulmaktaydı. Her MAP için en az bir Türk öğrenci mihmandar görevlendirilmekte ve her kursiyerin okulda çalışan personel aileleri ile mihmandar aile bağı kurularak Türk aile yaşantısını yakından tanıma imkânları sağlanmaktaydı.

Münazara, şiir ve güzel konuşma yarışmaları yapılmakta, müzik, folklor ve tiyatro çalışmaları icra edilmekteydi. Ülkelerin millî günleri törenlerle kutlanmakta, kursiyerlerin moral ve motivasyonlarını artırıcı konser, tiyatro, spor müsabakalarını izleme etkinlikleri icra edilmekteydi. Kursiyerlerin sağlık, barınma ve iaşe ihtiyaçları için gerekli önlemler alınmakta, maddî durumu iyi olmayan kursiyerler için de ilave tedbirler düşünülmekteydi. TSK'deki ATOTÖ etkinliğinde, "Seçmeci (Eklektik) Yöntem" uygulanmaktaydı. Türkçenin öğretiminde, dört dil becerisine (okuma, yazma, anlama, konuşma) imkânlar ölçüsünde yeterli zaman ayrılmakta ve dört temel beceriye de aynı derecede önem verilmekteydi.

“Bugüne kadar 54 dost ve müttefik ülkeye mensup 29.257 MAP'a eğitim / kurs verilmiştir. 2014-2015 döneminde 35 ülkeden 2.763, 2015-2016 döneminde 31 ülkeden 3.443 MAP'a eğitim / kurs verilmesi planlanmıştır. Ayrıca, mobil eğitim timleri vasıtasıyla kendi ülkelerinde; eğitim, öğretim ve çeşitli kurslar verilmektedir." Ayrıca "Somali Silahlı Kuvvetlerine mensup toplam 103 misafir askerî personel Türkiye'ye getirilmiştir. 11 Kasım 2014-24 Temmuz 2015 tarihleri arasında Kara Lisan Okulunda Türkçe Lisan Eğitimleri başlamıştır." ${ }^{1}$ Her yıl ortalama iki bin civarında yeni kursiyere Türkçe ve askerî eğitimler verilmektedir. 2015-2016 dönemine 3.443 MAP'e eğitim ve kurs verilmesinin planlandığı dikkate alındığında, gelecek yıllarda bu sayının katlanarak artacağı öngörülmektedir.

K.K.Lisan Okulunda 1977'den 2016 yılına kadar 45 ülkeden 2863 Misafir Askerî Personele Türkçe kursu verilmiştir. 2013-2014 eğitim-öğretim y1lında 110, 2014-2015 eğitim-öğretim yılında 102 Somalili kursiyere Türkçe kursu verilmiştir. Yurt dışında açılan dershanelerdeki dil kurslarında dereceye giren kursiyerlere, her yıl Ekim ayı içinde Türkiye'de bir hafta süreli kültür gezisi planlanmakta ve uygulanmaktaydı. Bu etkinliğin; kursiyerleri motive etmek, yerinde Türkçe eğitimi vermek, öğretmenler arasında iletişim kurmak ve dershanelerin eğitim düzeylerini takip etmek gibi pek çok yararları bulunmaktaydı. ${ }^{2}$ Yeni dönemde MAP'e Türkçe öğretiminin nasıl gerçekleştirileceği, Milli Savunma Üniversitesinin kurulması ve diğer okulların yeniden şekillenmesinden sonra ortaya çıkacaktır.

\section{MAP'a Türkçe öğretiminde karşıllaşıllan sorunlar}

Türkçenin söz dizimi, ses özellikleri ve alfabesi bazı MAP'in ana dilindeki yapılardan çok farklı olduğundan; bu kursiyerler Türkçenin sözdizimine uygun cümleler kurmada, sözcükleri doğru telâffuz etmede ilave güçlükler çekmektedir.

Türkçenin dil yapısında iyelik ekleri önemli bir yer tutmaktadır. Genellikle iyelik ekleri bazı şahıs ekleriyle karıştırılmakta bu da öğrenmeyi zorlaştırmaktadır. Örneğin "Ben öğretmen-im. "ve "ben-im ögretmen-im" ifadelerinde yazımları ve söylenişleri aynı olan üç farklı “-im” eki vardır. Bu eklerden birincisi 1. tekil şahıs, ikincisi ilgi durumu ve üçüncü de iyelik ekidir.

\footnotetext{
${ }^{1}$ http://www.tsk.tr/6_uluslararasi_iliskiler/tskaskeriegitimveisbirligifaaliyetleri.html_erişim tarihi: 18.08.2015

${ }^{2}$ K.K.Lis. Okl. K.lığında Mart 2015 itibariyle 12 farklı ülkeden toplam 165 MAP’e Türkçe öğretildiği öğrenilmiştir.
} 
Taştekin, A. (2017). Teaching Turkish to non-native speakers within the context of Turkish Armed Forces practices. International Journal of Social Sciences and Education Research, 3(1), 171-183.

Türkçenin aksine bazı dillerde durum ekleri bulunmadığından, bu dilleri konuşan MAP Türkçedeki durum eklerini kavramada zorlanmaktadır. Özellikle belirtme durumu eki “-i” ile yönelme durumu eki "-e"nin karıştırıldığı, belirtme durumu eki yerine hemen her yerde yönelme durumu ekinin kullanıldı̆̆ 1 , "Anneme yardım ettim." yerine, "Annemi yardım ettim" biçiminde cümleler kurulduğu görülmektedir.

Tek heceli, eklemeli ve çekimli dil ailelerine mensup kursiyerler; aynı sınıf ortamında ortak eğitim programına tabi tutulmakta, farklı alfabe ve dil becerisine sahip kursiyerler aynı koşullarda yarışmak durumunda kalmaktadır.

Türkçe Temel Kursu'na katılan MAP'in genellikle hiç Türkçe bilmediği, hatta birçoğunun Latin kökenli Türk alfabesiyle ilk defa karşılaştığı, bu nedenle az da olsa Türkçeye aşina olan diğer kursiyerlere nazaran bu öğrencilerin Türk dili ve kültürüne daha geç intibak sağladığ gözlenmiştir. Kursiyerler arasındaki yaş, cinsiyet, maddî durum, statü, Türk kültürüne aşina olmak ya da olmamak gibi faktörler nedeniyle iaşe, barınma vb. konularda bazı kursiyerler intibak güçlügü yaşamaktadır.

ATOTÖ konusunda üniversitelerimizde lisans programı olmadığından TSK'de MAP'e Türkçe öğretme görevini muvazzaf Türk dili ve edebiyatı öğretmenleri ile yabancı dil öğretmenleri yapmakta; ihtiyaç halinde yedek subaylardan ve TÖMER'ler ile halk eğitim müdürlüklerinde görevli sivil öğretmenlerden de yararlanılmaktadır.

TSK'nin açtığı yurt dışındaki Türkçe lisan dershanelerinde Türkiye' deki kurslarda başarılı olan bazı MAP veya Türkiye'den gönderilen muvazzaf öğretmen subaylar görev yapmaktadır. Ülkesinde Türkçe öğretmenliği yapacak MAP da Türkçe tekâmül kursunda yetiştirilmekte ancak uluslararası geçerlilikte öğretmenlik sertifikası verilememektedir.

TSK bünyesindeki kurumlarda 2004'e kadar ders kitabı olarak “Türkçe Öğrenelim” seti okutulmuş, bu tarihten sonra Ankara Üniversitesi TÖMER'in ürettiği ve kullandığ 1 "HITTIT Yabancılar İçin Türkçe” setine geçilmiştir. Bu kitaplarda askeri terminolojiyi öğretecek içerik bulunmadığından bu maksatla hazırlanan ilave kaynak kitap ${ }^{1}$ ve dokümanlar kullanılmaktadır. Ders kitapları kursiyerlere ücretsiz dağıtılmakta, böylece hem her dönem yenilenmiş kitaplardan yararlanmak mümkün olmakta hem de kursiyerler yanlarında götürmelerinde fayda olduğu düşünülen dokümanlara bedel ödemek zorunda kalmamaktadır.

\section{Sonuç ve öneriler}

2005 yllında ilk defa uygulanan ve halen devam ettirilen Türkçe Anlama Seviye Tespit Sınavı (TAS)'na göre yurt dışından kursiyer seçimi, Türkçe Tekâmül Kursu'nun kalitesine olumlu katkı sağlamaktadır. K.K.Lisan Okulunda verilen 36 haftalık Türkçe kursunun sonunda MAP, sınıf okulları ${ }^{2}$ ile harp akademilerindeki eğitim ve öğretimi takip edecek seviyede Türkçe öğrenmektedir. MAP'in bu seviyeye ulaşması için her türlü EYM ve metottan etkin şekilde yararlanılmaktadır. 2006 yılında açılan bilgisayar destekli eğitim dershaneleri ile konuşma kulüpler dört dil becerisinin gelişmesi için yeni imkânlar sunmaktadır.

\footnotetext{
${ }^{1}$ Türkçe Bölüm Başkanlığınca hazırlanan Askerî Terminoloji Kitabı kullanılmaktadır.

${ }^{2}$ Piyade, tank, topçu, ulaştırma vb. muharip ve yardımcı sınıfların eğitimi verilen kurumlara "sınıf okulu" denmektedir.
} 
Taştekin, A. (2017). Türk Silahlı Kuvvetlerinin uygulamaları bağlamında anadili Türkçe olmayanlara Türkçe öğretimi. International Journal of Social Sciences and Education Research, 3(1), 171-183.

Üretilen Müzikle Türkçe Öğretimi CD’si, Türkçe Dilbilgisi CD’si, Günlük Konuşma K1lavuzu, vb. EYM'lerin bilgisayar ortamında ve akıllı tahtalarda kullanılması kursiyerler üzerinde eğitim ve öğretim açısından olumlu etkiler sağlamaktadır. Okutulan ders kitaplarının hedef kitlesi askeri personel olmadığı için askerî terminolojiye yönelik ilave dokümanlardan yararlanılması meslekî Türkçe eğitimini olumlu yönde etkilemektedir.

Yurt dışındaki Türkçe lisan dershanelerini başarıyla bitiren kursiyerlerin bir hafta süreyle Türkiye'ye getirilmeleri, yurt dışında Türkçenin öğrenilmesine olan ilgiyi artırmakta, ülkeler arası dostluk ve kardeşlik duygularının pekişmesine imkân vermektedir. Kursiyerlere iaşe ve barınma imkânları sunma ve ihtiyacı olanlara maaş verme faaliyeti Türkçe eğitimini olumlu yönde etkilemektedir. Kursiyerlere mihmandar personel ve aile planlanması yapılması da Türk aile yaşantısını ve Türk kültürünü tanıtmak açısından yararlı olmaktadır. Ayrıca kursiyerlerin doğal ortamlarda Türkçe pratik yapmalarına imkân sağlamaktadır.

Türkiye geneli için ATOTÖ’ne yönelik problem sahalarını inceleyen, çözüm önerileri geliştiren ve sunan bir dil akademisi mevcut değildir. Böyle bir danışma ve koordinasyon merkezine ihtiyaç duyulmaktadır. Yurt içi ve yurt dışında yabancılara Türkçe öğretimiyle ilgilenen yerli kurum ve kuruluşlar (MEB, TSK, TDK, TÖMER, DİLMER, TIKA, YEE; Lisan Okulları $v b$.) arasında planlı bir koordinasyona ihtiyaç bulunmaktadır. Hiç olmazsa yılda bir defa bu kurum temsilcileri bir araya gelerek kurumsal gelişme ve değişimlerden birbirlerini haberdar etmeli ve görüşme sonuçları bir rapor halinde kamuoyuna duyurulmalıdır.

Türkiye ve yurt dışındaki ATOTÖ etkinliğinde bulunan yerli ve yabancı kurumların soru ve sorunlarıyla ilgilenen; bu kurslara katılan tüm yabancı öğrenciler için en azından danışmanlık hizmeti verebilecek ulusal bir merkez mevcut değildir. Yunus Emre Enstitüsü bu alandaki ihtiyacı gidermeye çalışmaktadır. Dünyada Türkçe öğrenme talebine paralel olarak, bu alanda nitelikli öğretmen ihtiyacının her geçen gün daha da artacağı değerlendirilmesine rağmen, АTOTÖ için üniversitelerde öğretmen yetiştiren lisans programları henüz açılmamıştır. Bazı sertifika programlarıyla bu konudaki ihtiyaca cevap verilmek istenmektedir.

Uzmanlarca hazırlanmış kursiyer/öğrenci görüntüsüne (profil) uygun standart ders programları yoktur veya kullanılanlar yetersizdir. İlk, ota ve yüksekokul düzeyindeki öğrenciler ile yetişkinlere uygun her grubun kendi ilgi alanlarındaki konuları içeren farklı kurlardaki EYM'ler mevcut değildir. Her kurumda ATOTÖ etkinliği kapsamında verilen kurslarda ders saatleri ve ders süreleri farklı farklı uygulanmaktadır. Hangi öğrenci/kursiyer kitlesine hangi düzeyde hangi konuların ne kadar sürede nasıl öğretilmesi gerektiğine dair bilimsel çalışmalara ihtiyaç bulunmaktadır.

ATOTÖ alanında TOEFL benzeri sınavla ölçme/değerlendirme yaparak, uluslararası geçerlilikte başarı belgesi verebilen bir kurum veya birim mevcut değildir. Türkiye'de öğrenim görecek veya görev alacak yabancılara dört dil becerisini ölçen sınav yapmak; verilecek eğitim/öğretimin kalitesini ve alınacak hizmetin niteliğini büyük ölçüde belirleyecektir.

Türkçe öğrenmek üzere Türkiye'ye gelen MAP'ın; Türkçeye olan ilgisini artırmak, ülkemizi ve kültürümüzü tanımasını sağlamak, dört dil becerisini aktif şekilde kullanmasına imkân vermek amacıyla yapılan ders nitelikli kültürel geziler ATOTÖ faaliyetinde bulunan sivil ve özel kurumlarca da icra edilmelidir. Yapılan gezilerin Türkiye genelindeki tarihî ve turistik yerleri kapsayacak şekilde düzenlenmesi, gezilerin daha etkin ve verimli olması için tecrübeli seyahat ve turizm şirketlerinden yararlanılması faydalı olacaktır. 
Taştekin, A. (2017). Teaching Turkish to non-native speakers within the context of Turkish Armed Forces practices. International Journal of Social Sciences and Education Research, 3(1), 171-183.

Anadili Türkçe olmayanların Türkçe kelime dağarcığını geliştirmek ve okuma alışkanlıklarını kalıcı hale getirmek amacıyla, her kademede kursiyer/öğrenci seviyelerine uygun yardımcı okuma ve dil bilgisi kitapları ile sözlükler üretilmelidir. ATOTÖ konusunda görevlendirilecek personelin bu konuda tecrübeli kişiler arasından seçilerek atanmasına özen gösterilmelidir. Öğretmen yetiştirmeye özel önem verilmelidir. Unutulmamalıdır ki öğretmen yetersizliği; Türkçenin öğretilememesinin yanı sıra Türk kültürüne yabancılığı, hatta nefreti de körükleyebilmektedir.

Türkiye ve yurt dışında yabancılara Türkçe öğreten tüm kurum ve kuruluşların eşgüdümünden sorumlu bir sivil kurumun belirlenmesi; tanıtım, iletişim ve birikimlerin paylaşımı açısından yararlı olacaktır. TSK bünyesinde MAP'e Türkçe eğitimi veren kurum ve birimler arasında kitap, yöntem, EYM vb. konularda yeni gelişmeler ışığında işbirliği sürdürülmeli, aynı iş birliği ilgili sivil kurumlarla da sağlanmalıdır.

ATOTÖ konusunda ülkemizde yapılan her türlü bilimsel toplant1, kurs ve seminerlere katılım sürdürülmeli ve bu konuda açılan yüksek lisans programlarına personel teşvik edilmelidir. Yurt dışındaki Türkçe lisan dershanelerinin eğitim ortamı ve EYM açısından ihtiyaçlarının tespiti ve gerekli koordinasyon için, her yıl bir plan dâhilinde ziyaret edilmesi ve sivil kurumlar arasında da benzer koordinasyon ziyaretlerinin planlanması yararlı olacaktır.

Yurt dışındaki Türkçe lisan dershanelerine görevlendirilecek personele göreve gitmeden önce iki hafta süreyle ATOTÖ konusunda intibak eğitimi verilmesi önem arz etmektedir. Aynı şekilde üniversitelerin ve MEB'nın yurt dışında yabancılara Türkçe öğretmek üzere ilk defa görevlendireceği personele de yeterli süre ve içerikte intibak kursu verilmelidir. Yurt dişındaki ATOTÖ faaliyetinde bulunan özel veya resmî kurumlarda dereceye giren kursiyerlerin TSK örneğinde olduğu gibi bir hafta süreyle Türkiye'de kültür gezisine katılmaları faydalı olacaktır.

K.K.Lisan Okulunda gördükleri Türkçe kursundan sonra harp akademileri ile sınıf okullarına giden MAP'in Türkçe dil becerileri yönünden izlenmesi için ilgili kurumlarla irtibatın sürdürülmesi ve kursiyerlerin yerinde ziyaret edilmesi faaliyeti, benzer işlevleri olan sivil kurumlarca da icra edilmelidir. Alınan geri bildirimler hizmetin kalitesini artırma açısından önemli olmaktadır.

ATOTÖ konusunda hizmet üreten kurumlarca, yaşanan sıkıntıların tespiti ve alınacak ilave önlemlerin belirlenmesi için, deneysel araştırmaların nitelik ve nicelik bakımından artırılmasına yönelik önlemler alınmalıdır. Öğretim programlarının uzman kişilerce hazırlanması veya programların güncellenecek olması halinde, çalışma grubuna TSK'den ve ilgili üniversitelerden de personel dâhil edilmelidir. Bu sayede kurumların farklı izlenim ve tecrübelerinden yararlanmak mümkün olacaktır. Programlarda gramer odaklı yöntemler yerine, dil bilgisini hissettirmeden veren teknikler tercih edilmelidir.

ATOTÖ faaliyetinde teknolojinin sağladığı imkânlardan azami ölçüde faydalanılmalı, görsel nitelikli ve içeriği kapsamlı resmi Genel Ağ sayfaları oluşturulmalıdır. Uzaktan eğitip programları nitelik ve nicelik bakımından geliştirilmelidir. Farklı ülkelerin değiş̧ik dil bilgi ve becerisi olan yetişkinlerine Türkçe öğretirken, tüm insanlığın ortak dili sayılan resim ve şekillerin gücünden yararlanılmalıdır. Öğretimde dilin anlamlı bir yargı bildiren temel unsuru olan cümle esas alınmalı, Türk alfabesini bilmeyenlere, öncelikle resimli alfabelerle yazı dilinin en küçük birimi olan harfler öğretilmelidir. 
Taştekin, A. (2017). Türk Silahlı Kuvvetlerinin uygulamaları bağlamında anadili Türkçe olmayanlara Türkçe ögretimi. International Journal of Social Sciences and Education Research, 3(1), 171-183.

Öğrencilere kelime ezberletmek yerine, kelimenin anlam ve şekil bilgisi cümle içinde verilmeli, Türkçedeki zaman ve kişi durumları da cümlede kavratılmalıdır. Cümleler öğretilirken önce cümlenin doğru okunması, doğru anlaşılması ve doğru ifade edilmesi (önce sözlü, sonra yazılı olarak) sonra da cümlenin yapısının çözümlenmesi ve benzer cümleler üretilmesi öğretilmeli; vurgu, tonlama ve yazım kuralları cümle ile birlikte kavratmalıdır.

Türk soylulara Türkçe öğretimi ile yabancılara Türkçe öğretimi aynı sayılmamalıdır. Bu konuda bir devlet politikası oluşturulmalı, çağdaş Türk lehçelerinin öğretimi ile ATOTÖ faaliyetinin kapsamı, içeriği ve öğretim yöntemi bilimsel ölçütlere göre değerlendirilmeli, meslekî Türkçe öğretimine yönelik önlemler de alınmalıdır.

\section{Kaynakça}

Açık, F. (2008). Türkiye'de Yabancılara Türkçe Öğretilirken Karşılaşılan Sorunlar ve Çözüm Önerileri, (Doğu Akdeniz Üniversitesi Eğitim Fakültesi Türkçe Eğitimi Bölümü “Uluslararası Türkçe Eğitimi ve Öğretimi Sempozyumu”), Kıbrıs, 27-28 Mart.

Akış, İ. (2010). Türkçenin Yabancı Dil Olarak Öğretimi İle İlgili Ana Sorunlar, E. Uzun, E. Gökmen ve C. Kurt (Ed.), 8. Dünyada Türkçe Öğretimi Sempozyumu içinde (s.202-203). Ankara: Ankara Üniversitesi TÖMER.

Alyılmaz, C. (2010). Türkçe Öğretiminin Sorunları. Turkish Studies International Periodical For the Languages, Literature and History of Turkish or Turkic, Volume 5/3 Summer.

Bağdaş, F. Ş. (2011). Hava Harp Okulunda Öğrenim Gören Yabancı Öğrencilerin Türkçe Öğrenmede Karşılaştıkları Güçlükler. (Yayımlanmamış Yüksek Lisans Tezi), Marmara Üniversitesi Eğitim Bilimleri Enstitüsü. Ankara.

Bağdaş, F. Ş. (2015). Yabancılara Türkçe Öğretiminde Türk Silahlı Kuvvetlerinin Yeri: Afganistan Örneği, http://www.turkcede.org/yeni-ogrenenlere-turkce-ogretimi/1587, erişim tarihi: 18.08.2015.

Biçer, N., Çoban, İ. ve Bakır, S. (2014). Türkçe Öğrenen Yabancı Öğrencilerin Karşılaştığı Sorunlar: Atatürk Üniversitesi Örneği, Uluslararası Sosyal Araştırmalar Dergisi The Journal of International Social Research Cilt: 7 Sayı: 29 Volume: 7 Issue: 29.

Er, O., Biçer, N. Ve Bozkırl, K. Ç. (2012). Yabancılara Türkçe Öğretiminde Karşılaşılan Sorunların İlgili Alan Yazını Işı̆̆ında Değerlendirilmesi, Teke Uluslararası Türkçe Edebiyat Kültür Eğitim Dergisi, Sayl: 1/2, s. 51-69.

Göçer, A. Ve Moğul, S. (2011) Türkçenin Yabancı Dil Olarak Öğretimi İle İlgili Çalışmalara Genel Bir Bakış, Turkish Studies - International Periodical For The Languages, Literature and History of Turkish or Turkic, Volume 6/3 Summer, p. 797-810.

Göçer, A., Tabak, G. Ve Coşkun, A. (2012) Türkçenin Yabancı Dil Olarak Öğretimi Kaynakçası, TÜ$B A R$-XXXII, file:///C:/Users/alitastekin/Downloads/5000073169-5000097892-1-PB.pdf, erişim tarihi: 18.08.2015.

Kahriman, R., Dağtaş, A., Çapoğlu, E. ve Ateşal, Z. (2013). Yabancılara Türkçe Öğretimi Kaynakçası, Türük Dil, Edebiyat ve Halkbilimi Araştırmaları Dergisi, Yı1:1, Sayı:1, Sayfa: 80-132.

Kara, M. (2010). Gazi Üniversitesi Tömer Öğrencilerinin Türkçe Öğrenirken Karşılaştıkları Sorunlar ve Bunların Çözümüne Yönelik Öneriler, Türk Eğitim Bilimleri Dergisi, 8(3), 661-696.

Karababa, Z. C. (2009). Yabancı Dil Olarak Türkçenin Öğretimi ve Karşılaşıllan Sorunlar, Ankara Üniversitesi Ĕ̈itim Bilimleri Fakültesi Dergisi, 42(2), 265-277. 
Taştekin, A. (2017). Teaching Turkish to non-native speakers within the context of Turkish Armed Forces practices. International Journal of Social Sciences and Education Research, 3(1), 171-183.

Mavaşoğlu, M. ve Tüm, G. (2010). Türkçenin Yabancı Dil (TYD) Olarak Öğretiminde Çukurova Üniversitesinin Uygulamaları, Karşılaşılan Sorunlar ve Çözüm Önerileri. Sunum, s.1-9.

MSB. (2015). 2011 Y1l Faaliyet Raporu, sahife:31, http://www.turksavunmasanayihaber.com, erişim tarihi: 18.08.2015.

Şengül, K. (2014). Türkçenin Yabancı Dil Olarak Öğretiminde Alfabe Sorunu, Teke Uluslararası Türkçe Edebiyat Kültür Eğitim Dergisi, Sayı: 3/1, s. 325-339.

Ünlü, H. (2011). Türkiyede Ve Dünyada Türkçenin Yabancılara Öğretiminde Karşılaşılan Sorunlar Ve Çözüm Önerileri, Gazi Üniversitesi Türkçe Araştırmaları Akademik Öğrenci Dergisi, Yı1:1, Sayı:1.

Yıldız, Ü. ve TUNÇEL, H. (2012). Yabancı Dil olarak Türkçe Öğretiminde Karşılaşılan Sorunlar ve Öneriler. İçinde: Aziz Kılınç ve Abdullah Şahin (Editörler), Yabancı Dil Olarak Türkçe Öğretimi (YDTÖ). (Sayfa: 115-145), Ankara: Pegem Akademi.

\section{Extended Abstract in English}

When historical, geographical and cultural domains of Turkish language are considered, it is commented that the interest of foreigners in Turkish language, especially in the dialect spoken in Turkey will gradually rise and the activity of Teaching Turkish to Non-Native Speakers will gain more importance.

The historical process of Turkish Armed Forces' activities concerning teaching Turkish to foreigners has not yet been completely identified. However, the first known Turkish language education given to Guest Military Personnel after the foundation of Turkish Republic was recorded in the enactment signed by Ghazi Mustafa Kemal on 24 April 1933 and issued 14234 on "the admittance decree regarding the Saudi Arabia Government's wish to send students to "Türkiye Harp ve Tayyare Mektepleri" (Turkish Schools of War and Aviation) and this is acknowledged as the beginning of this practice.

It was observed that in this Teaching Turkish to Non-Native Speakers activity performed by Turkish Armed Forces, "Eclectic Method" was applied and four language skills (reading, writing, comprehension, speaking) were allocated an adequate amount of time and the same amount of importance within the bounds of possibility while teaching Turkish. In order to make this exemplary practice of Turkish Armed Forces known in the science world, it would be beneficial to include topics such as "Teaching Turkish for Professional Purposes" and "Teaching Turkish to non-native adults for specific purposes," etc. in national and international workshops.

There are certain relative problems in teaching Guest Military Personnel Turkish as a foreign language. It was determined that these problems were tried to be solved by means of additional precautions and that selecting the trainees from abroad according to TAS exams first applied in 2005 has had a positive contribution to the quality of Türkçe Tekâmül Kursu (Turkish Improvement Course).

Precautions must be taken in order to increase the number of experimental research made to identify the problems encountered in teaching Turkish to foreigners. Training programs must be prepared by experts and Turkish Armed Forces staff should also be included in research groups to be founded for the update of the program. 
Taştekin, A. (2017). Türk Silahlı Kuvvetlerinin uygulamaları bağlamında anadili Türkçe olmayanlara Türkçe öğretimi. International Journal of Social Sciences and Education Research, 3(1), 171-183.

The opportunities provided by technology must be utilized at utmost capacity and the number and quality of websites rich in images and extensive contents must be increased. Language acquisition techniques instead of grammar based methods must be embraced in this activity we call Teaching Turkish to Non-Native Adults.

My aim in this study is to identify the outcome gained in the light of the accumulation achieved by 31 years of service as a Turkish language teacher and administrator at several educational institutions of Turkish Armed Forces teaching military students at various ages and teaching Guest Military Personnel Turkish for 11 years.

Turkish language education for Guest Military Personnel (GMP) provided by Turkish Armed Forces (TAF) was delivered at Land Forces Language School for high-ranking personnel from every force and students were offered this education at their own school grounds. The Guest Military Personnel learning Turkish at military high schools, military schools, Gülhane Military Medical Academy, service schools and military academies were called as students whereas high-ranking personnel learning Turkish at other institutions such as language schools were called as trainees.

Until recently, GMP from friendly and allied nations coming to Turkey to study at military schools, NCO vocational schools and some military high schools were offered one year long Turkish language education at Turkish preparatory classes within the scope of Military Training Cooperation agreements.

Turkish language education provided at Land Forces Language School covered the training of GMP which were prospective military academy and service school students and prospective Turkish language teachers expected to teach at language schools in their home countries. This school offered a 36-week Turkish basics - improvement program and a 13-week Turkish Improvement Course with six hours of class hour per day, five days of the week and the classes consisted of 15 people maximum.

In order to coordinate all educational institutions providing Turkish language education for GMP within TAF and enable sharing educational materials, Turkish General Staff has formed a Teaching Turkish as a Foreign Language Study Group. Within the same scope, sharing materials related to Turkish language teaching has been made more practical by adding a Turkish page for GMP to Land Forces Language Education Portal prepared in 7 different languages by Land Forces Language School.

As well as curricular Turkish language education provided in a classroom environment by Land Forces Language School, the Study Group has organized extra-curricular Cultural Educational Trips during the week and Social Activities at the weekend in order to present the beauties of our country, the richness of Turkish culture and the hospitality of our people while enabling the students to practice their language skills in historical and touristic settings. Also, a monthly informative document titled "Türkçenin Sesi" ("The Voice of Turkish") for the use of GMP was prepared and it was made sure that the trainees who were studying Turkish read this document. In this way, as well as learning how to speak Turkish, GMP also became friends to Turkish people by the time they graduated from Land Forces Language School having learned about Turkish culture, traditions and customs.

Extra-curricular educational environments were furnished with opportunities to learn and practice Turkish; GMP could watch Turkish television in the guest house and were provided 
Taştekin, A. (2017). Teaching Turkish to non-native speakers within the context of Turkish Armed Forces practices. International Journal of Social Sciences and Education Research, 3(1), 171-183.

with computers, cassette / cd players and other necessary tools and equipment. At least one Turkish student was appointed as host to each GMP and it was made sure that each trainee had familial bonds with the hosts' and staff's families in order to get to know Turkish family life closer.

Debate, poetry and eloquence contests were organized and music, folklore and drama shows were staged. National days were celebrated and concerts, plays and sports competitions were organized to motivate the trainees and keep their spirits high. Necessary precautions were taken for the trainees' health, accommodation and catering needs and additional measures were considered for trainees who had lower incomes.

There is a need got a planned coordination between national institutions and organizations (such as MNE, TAF, TDK (Turkish Language Institution), TÖMER, DILLMER, TIKA, (Turkish Cooperation and Coordination Agency), YEE (Yunus Emre Foundation), Language schools, etc.) involved in Turkish language teaching to foreigners both at home and abroad. Representatives of these institutions should gather at least once a year and share institutional developments and changes and report the discussions to the public. 